\title{
LITERATURE REVIEW: DAMPAK ANEMIA DEFISIENSI BESI PADA IBU HAMIL
}

\author{
Anjar Fifi Wulandari ${ }^{1}$, Emi Sutrisminah ${ }^{2}$, Is Susiloningtyas ${ }^{3}$ \\ Universitas Islam Sultan Agung Semarang ${ }^{123}$ \\ e-mail: ${ }^{1}$ anjarfifi2@gmail.com
}

\begin{abstract}
In general, the most common cause of anaemia in pregnancy is iron deficiency, which arises from maternal-fetal iron transfer, which is often exacerbated by a decrease in maternal iron stores. According to the World Health Organization (WHO), pregnancy anaemia is a global health problem that affects almost half of pregnant women. The purpose of this study was to conduct a journal review of explanatory and experimental articles published in the last 5 years starting in 2016 on deficiency anaemia in pregnancy. The research method is carried out by literature study using an electronic reference library through Medline, PubMed, NCBI, Science Direct and Proquest by investigating the impact of anaemia in pregnant women. The results literature from research in various developing and developed countries show that there is an impact that occurs when the mother had anaemia during pregnancy, namely prematurity, low birth weight, postpartum hemorrhage, maternal mortality, cesarean delivery and mental development of children. The conclusion is that there are several effects of anaemia in pregnant women, which are prematurity, low birth weight, postpartum hemorrhage, maternal mortality, cesarean delivery and children's mental development.
\end{abstract}

Keywords: anaemia; pregnant women; impact of pregnancy; iron deficiencies

\begin{abstract}
ABSTRAK
Pada umunya penyebab paling umum dari anemia pada kehamilan adalah defisiensi zat besi, yang timbul dari transfer zat besi dari ibu ke janin, yang seringkali diperburuk oleh penurunan penyimpanan zat besi ibu. Menurut Organisasi Kesehatan Dunia (WHO), anemia kehamilan merupakan masalah kesehatan global yang menyerang hampir setengah dari wanita hamil. Tujuan dari penelitian ini adalah untuk melakukan review jurnal terhadap artikel eksplanatori dan eksperimental yang diterbitkan dalam 5 tahun terakhir mulai tahun 2016 tentang anemia defisiensi pada kehamilan. Metode penelitian dilakukan dengan studi pustaka menggunakan perpustakaan referensi elektronik melalui Medline, PubMed, NCBI, Science Direct dan Proquest yang menggali tentang dampak anemia pada wanita hamil. Hasil literatur dari penelitian di berbagai negara berkembang dan maju menunjukkan bahwa terdapat dampak yang terjadi bila ibu mengalami anemia selama kehamilan yaitu mengalami prematuritas, berat badan lahir rendah, perdarahan postpartum, kematian ibu, persalinan caesar dan perkembangan mental anak. Kesimpulannya adalah terdapat beberapa efek anemia pada ibu hamil yaitu mengalami prematuritas, berat badan lahir rendah, perdarahan postpartum, kematian ibu, persalinan caesar dan perkembangan mental anak. Kata kunci: anemia; wanita hamil; dampak kehamilan; defisiensi besi
\end{abstract}

\section{PENDAHULUAN}

\section{Latar Belakang}

Anemia defisiensi besi (IDA) menjadi penyebab utama lima tahun hidup dengan kecacatan pada manusia terutama pada wanita ${ }^{(1)}$. Walaupun telah dianggap sebagai masalah kesehatan masyarakat yang berpengaruh pada pertumbuhan anak, premenopause dan wanita hamil, hal ini juga semakin diakui sebagai kondisi klinis yang dapat mempengaruhi pasien yang datang ke berbagai spesialisasi medis dan bedah, terutama yang memiliki kondisi kronis dan lansia (2).

Anemia kehamilan merupakan permasalahan kesehatan global yang mempengaruhi hampir setengah dari wanita hamil. Organisasi Kesehatan Dunia (WHO) mendefinisikan anemia kehamilan sebagai hemoglobin $(\mathrm{Hb}), 11 \mathrm{~g} / \mathrm{dL}$, atau hematokrit, $33 \%$, pada saat kehamilan. Pusat Pengendalian dan Pencegahan Penyakit (CDC) mendefinisikan anemia kehamilan sebagai $\mathrm{Hb}, 11 \mathrm{~g} / \mathrm{dL}$, atau hematokrit, $33 \%$ selama trimester pertama dan ketiga, dan 10,5 g / dL atau hematokrit, $32 \%$ pada 
trimester kedua. WHO menyatakan anemia berat untuk setiap orang yaitu dengan $\mathrm{Hb} 7 \mathrm{~g} / \mathrm{dL}$ dan anemia sangat berat dengan $\mathrm{Hb} 4 \mathrm{~g} / \mathrm{dL}{ }^{(3)}$.

Pada umumnya penyebab paling sering terjadinya anemia pada kehamilan adalah defisiensi zat besi, yang timbul dari transfer zat besi ibu-janin, yang tidak jarang diperburuk oleh penurunan cadangan zat besi ibu. Studi Model Dampak Gizi, analisis sistematis dari 257 data perwakilan populasi dari 107 negara, prevalensi global anemia pada kehamilan diperkirakan sebesar $43 \%$ pada tahun 1995 dan 38\% pada tahun $2011^{(3)}$

Menurut WHO (World Health Organization) dan Bailit JL dkk anemia mempengaruhi sekitar $40 \%$ dari wanita hamil di seluruh dunia dan hampir sepertiga dari wanita hamil di Amerika Serikat. Menurut Kidanto HL dkk Anemia pada kehamilan telah dikaitkan dengan tingkat kematian ibu yang lebih tinggi, kematian perinatal, kelahiran prematur, preeklamsia, berat badan lahir rendah, kelahiran hidup kecil untuk usia kehamilan (SGA), dan persalinan sesar. Risiko efek samping ini mungkin sebanding dengan tingkat keparahan anemia angka kelahiran prematur dan berat badan lahir rendah secara nyata meningkat di antara wanita dengan kadar hemoglobin kurang dari $7 \mathrm{~g} / \mathrm{dL}{ }^{(4)}$.

Dampak resiko ibu hamil dengan anemia yaitu kelelahan, pucat, takikardia, toleransi olahraga yang buruk, dan kinerja kerja yang kurang optimal. Selain itu menyebabkan kehilangan cadangan darah selama persalinan yang dapat meningkatkan kebutuhan transfusi darah, preeklamsia, solusio plasenta, gagal jantung, dan kematian ${ }^{(3)}$.

\section{Tujuan Penelitian}

Tujuan literature review ini yakni untuk mengidentifikasi dampak buruk yang dapat diakibatkan dari anemia pada ibu hamil dengan memberikan gambaran negatif dari anemia defisiensi besi terhadap ibu dan bayinya. Literature review ini penting untuk dilakukan karena anemia pada ibu hamil di Indonesia masih sangat banyak dan kurangnya kesadaran ibu hamil akan banyaknya dampak buruk yang dapat diakibatnya dari anemia pada saat kehamilan. Hal ini dilakukan dengan cara mengumpulkan artikel eksplanatori dan eksperimental pada 5 tahun terakhir.

\section{METODE}

Pada literature review pencarian artikel ini dilakukan dengan menggunakan electronic references library melalui Medline, PubMed, NCBI, Science Direct dan Proquest. Penelusuran artikel menggunakan kata kunci Anemia in Pregnancy AND Impact of Iron Deficiency in Pregnancy OR Antenatal OR Perinatal OR Maternal. Artikel yang direview merupakan artikel yang dipublikasikan dalam waktu 5 tahun terakhir, full text, berbahasa Indonesia dan Inggris dan dengan subyek wanita. Pencarian artikel dilakukan dari bulan Desember 2020 oleh satu peneliti dan diperoleh sebanyak 60 artikel. Hasil pencarian dan pemilihan artikel terhadap judul, abstrak dan full text didapatkan ada 23 artikel asli yang sesuai dengan kriteria inklusi kemudian melakukan telaah jurnal.

\section{HASIL DAN PEMBAHASAN}

\section{Dampak Anemia Defisiensi Besi pada Ibu Hamil dengan Bayi Prematur dan BBLR}

Pada 39.439 wanita dengan kehamilan tunggal menunjukkan ibu dengan kategori kelompok anemia dan kelompok yang tidak anemia. Bahwa adanya peningkatan prevalensi wanita dengan anemia pada kejadian polihidramnion, kelahiran prematur, berat badan lahir rendah $(<2500 \mathrm{~g})$, komplikasi neonatal dan penerimaan Neonatal Intensive Care Unit (NICU) sedangkan pada wanita yang tidak mengalami anemia terdapat peningkatan pada Gestasional Diabetes Melitus (GDM), gawat janin dan oligohidramnion yaitu $P<0,05$ signifikan secara statistik. Angka kejadian anemia meningkat secara sistematis dari awal kehamilan $(2,7 \%)$ hingga kehamilan tengah (14,7\%), kemudian menjadi yang tertinggi pada kehamilan lanjut $(16,6 \%)$. Telah menjadi dugaan bahwa anemia pada ibu hamil dapat meningkatkan terjadinya kelahiran prematur, gangguan tekanan darah tinggi dan berat badan lahir rendah. terdapat hubungan antara pada ibu hamil anemia dengan penerimaan bayi NICU yang disebabkan oleh angka kejadian dengan bayi prematur dan Berat Badan Lahir Rendah (BBLR) yang lebih tinggi pada ibu yang mengalami anemia ${ }^{(5)}$. 
Kelahiran prematur merupakan hal yang berkaitan dengan kejadian anemia pada ibu hamil dibandingkan dengan ibu yang tidak mengalami anemia (nilai $\mathrm{p}<0,05$, yaitu nilai $\mathrm{p}=0,000$ ). Anemia sering ditemukan pada ibu hamil karena terjadinya perubahan sel darah merah sesuai dengan usia kehamilannya. Kebutuhan oksigen yang lebih tinggi menyebabkan meningkatnya volume plasma darah dan eritrosit. Namun produksi volume plasma yang meningkat lebih besar dan terjadinya penurunan hemoglobin menyebabkan terjadinya anemia fisiologi ${ }^{(6)}$.

Karakteristik umum bayi baru lahir, diamati bahwa berat badan lahir berkorelasi positif dengan panjang $(r=0,72 ; p=0,0001)$ dan lingkar kepala $(r=0,57 ; p=0,0001)$. Lingkar kepala dikaitkan dengan kecenderungan Indeks Massa Tubuh (IMT) sebelum hamil $(\mathrm{r}=0,30 \mathrm{p}=$ $0,07)$ dan usia ginekologis $(r=0,28 \mathrm{p}=0,07)$. konsentrasi zat besi ibu hanya berhubungan dengan bayi baru lahir jika ibu mengalami anemia. konsentrasi zat besi dan Transferrin saturation (TSAT), baik dari wanita hamil anemia maupun wanita hamil non-anemia, menunjukkan korelasi positif yang signifikan dengan konsentrasi feritin di Umbilical Cord Blood $(U C B)$ atau darah tali pusat bayi baru lahir, hal ini menunjukkan bahwa terdapat faktor penting yang berhubungan langsung dengan penyimpanan zat besi anak. Pada saat bayi lahir anemia defisiensi besi maternal ringan atau sedang tidak menyebabkan simpanan zat besi rendah (ferritin) pada janin, tetapi dapat berkembang menjadi persalinan prematur dan bayi baru lahir dengan berat lahir rendah ${ }^{(7)}$.

Anemia defisiensi zat besi berhubungan dengan tingginya angka kelahiran prematur, berat badan lahir rendah (BBLR), dan bayi baru lahir dengan usia kehamilan kecil (SGA). Kekurangan zat besi pada ibu mempengaruhi konsentrasi zat besi dalam darah tali pusat. Defisiensi zat besi pada janin menyebabkan berkurangnya pengenalan pendengaran memori pada bayi, cerminan dari dampaknya pada perkembangan hipokampus. Anak-anak yang lahir dari ibu yang kekurangan zat besi menunjukkan gangguan belajar dan memori yang dapat berlanjut hingga dewasa. Kekurangan asam folat, terutama pada saat pembuahan, sangat berkorelasi dengan peningkatan Neural Tube Defects (NTDs). Rendahnya sel darah merah folat ibu juga dikaitkan dengan BBLR, dan peningkatan risiko SGA. Status vitamin B12 (cobalamin) ibu mempengaruhi pertumbuhan dan perkembangan janin ${ }^{(3)}$.
Konsentrasi serum feritin didalam tali pusat saat persalinan menyebabkan hipertrofi plasenta dan anemia pada ibu dapat meningkatkan terjadinya resiko kelahiran dengan bayi prematur, berat badan lahir rendah hingga kematian bayi. BBLR dapat dikaitkan dengan kehamilan anemia pada trimester pertama. Dalam penelitian ini suplemen Fe dapat menurunkan frekuensi anemia sebesar $73 \%{ }^{(8)}$.

Kejadian ibu yang mengalami anemia memiliki angka resiko lebih besar yaitu sebesar $70 \%$. Hasil uji chi square yang didapatkan menunjukkan anemia pada ibu saat hamil sebagai faktor risiko kejadian BBLR $(\mathrm{p}=0,001)$, sedangkan nilai OR membuktikan bahwa ibu yang mengalami anemia 9 kali lebih berisiko melahirkan bayi dengan BBLR dibandingkan dengan ibu yang tidak anemia pada saat hamil hal ini dikarena perubahan fisiologis pada saat kehamilan terjadi penurunan kadar sel darah merah yang mempengaruhi oksigen ke rahim sehingga berdampak pada janin lahir dengan BBLR $^{(9)}$.

Dalam analisis regresi logistik, wanita anemia memiliki keterkaitan yang kuat (OR, 3.4) dan signifikan secara statistik $(P=.0001)$ lebih berisiko prematur dibandingkan dengan wanita yang tidak anemia. Sedangkan wanita anemia memiliki risiko BBLR yang signifikan secara statistik $(\mathrm{P}=.0003)$. Secara umum, prevalensi anemia memiliki keterkaitan cukup tinggi terhadap kelahiran prematur dan BBLR. Hal ini menunjukkan faktor resiko merugikan yang tinggi pada prematur dan BBLR ${ }^{(10)}$.

Anemia pada kehamilan meningkatkan kelahiran beresiko di Negara Asia Selatan. Anemia pada ibu hamil dapat meningkatkan bayi prematur dan kematian perinatal secara signifikan hal ini ditunjukkan dengan rasio odds yang dikumpulkan dari 25 studi dengan peluang BBLR (OR, 1.90, 95\% CI, 1.06-2.60, p < 0.05), Prematur (OR, 1,96, 95\% CI, 1,20-2,41 p <0,05) dan kematian perinatal (OR, 2,90, 95\% CI, 1,97$3,78 \mathrm{p}<0,05)$. Hal ini berhubungan dengan penurunan fisiologis kadar hemoglobin selama kehamilan yang menyebabkan volume plasma normal dan peningkatan massa sel darah merah. Perubahan ini berkontribusi pada konsentrasi hemoglobin. Penurunan konsentrasi hemoglobin dapat mempengaruhi berat lahir janin ${ }^{(11)}$.

\section{Dampak Anemia Defisiensi Besi pada Ibu Hamil dengan Pendaharan Postpartum dan Mortalitas Maternal}


Di India, New Delhi menunjukkan tidak adanya hubungan yang signifikan antara anemia ( $\mathrm{Hb} 8-10,9 \mathrm{gr} / \mathrm{dl} \%$ ), dengan usia kehamilan saat persalinan, cara persalinan, tingkat persalinan dengan alat tetapi anemia pada kehamilan berkaitan dengan peningkatan risiko BBLR dan kecil untuk usia kehamilan. Terdapat dua kelompok dengan insiden retardasi pertumbuhan intrauterin (IUGR) $(7,3$ vs. $8,0 \%, P=0,06)$ masing-masing dari kedua kelompok tersebut terjadi satu kematian neonatal. Penyebab dari kematian pada bayi tersebut dengan kelainan jantung kongenital, berat lahir rendah (BBLR) dan bayi IUGR dengan asfiksia lahir. Dari 328 neonatus, $19(10,6 \%)$ dan $20(13,4 \%)$ masingmasing dirawat di NICU $(\mathrm{P}=0,43)$. Ibu hamil anemia memerlukan pemantauan karena mereka tidak dapat mengalami kehilangan darah sebelum atau selama persalinan dan lebih rentan terhadap infeksi. Anemia menyebabkan PPH yang berkaitan dengan perdarahan antepartum (APH) (12).

Anemia dapat menyebabkan terjadinya perdarahan postpartum 5 kali lebih berisiko daripada ibu yang tidak mengalami anemia hal ini ditunjukkan dengan nilai (OR 5,096 OR > 1). Anemia pada kehamilan menjadi faktor utama kematian maternal terjadinya perdarahan, persalinan lama dan infeksi ${ }^{(13)}$.

Hasil penelitian ibu hamil anemia dengan perdarahan postpartum di RSUD Panembahan Senopati Bantul pada tahun 2015 dengan hasil uji chi square test menunjukkan nilai $p$ value $0,015<$ dari nilai $\alpha=0,05$ dan hasil analisis OR 4,846 OR $>1$ hal ini menunjukkan bahwa terdapat hubungan antara anemia dengan perdarahan postpartum sehingga disimpulkan bahwa ibu bersalin dengan anemia berisiko 4,8 kali mengalami perdarahan postpartum dengan ibu yang tidak mengalami anemia ${ }^{(14)}$.

Anemia berat pada kehamilan dapat menyebabkan kematian pada ibu hal ini ditunjukkan dengan skor kecenderungan analisis regresi yang menunjukkan hubungan antara anemia berat dan kematian ibu (OR 1 - 86 [95\% CI 1 • 39-2 · 49], p <0 • 0001. Dari Survei Multinegara WHO di 29 negara, kemungkinan kematian ibu dua kali lebih tinggi pada mereka yang mengalami anemia berat dibandingkan dengan mereka yang tidak mengalami anemia berat ${ }^{(15)}$.
Anemia pada kehamilan mengakibatkan dampak buruk pada ibu dan janin yang berkaitan dengan prevalensi morbiditas dan mortalitas. Ibu dengan anemia tidak jarang mengalami kesulitan dalam bernapas, cepat lelah, sulit beristirahat, jantung berdebar hingga pingsan. Dalam perinatal juga dapat mengakibatkan terjadinya infeksi perinatal, preeklampsia dan perdarahan. Janin dapat mengalami keterlambatan perkembangan intrauterin, premature dan BBLR ${ }^{(16)}$.

\section{Dampak Anemia Defisiensi Besi pada Ibu Hamil dengan Persalinan Sesar}

Hubungan anemia ibu hamil dapat merugikan hasil kehamilannya. Hal ini dikaitkan dengan meningkatnya resiko persalinan sesar. Hal ini ditunjukkan dengan hasil penelitian terkait dengan hasil merugikan kehamilan pada ibu anemia dengan persalinan sesar (OR, 1,65; CI 95\%:1,29-2,11), anemia pascapartum (OR, 3,07, 95\% CI:1.83-5.15), transfusi darah (OR, 2.90; 95\% CI: 1.34-6.28), dan induksi persalinan (OR, 1.27; 95\% CI: $1.05-1.55)$. Meta analisis dosis respon dilakukan dari 42 studi, yang 22 melaporkan BBLR dan Prematur, 11 tentang SGA, 9 tentang kematian perinatal, 8 tentang preeklamsia, 7 tentang diabetes gestasional, 5 tentang perdarahan postpartum, dan 4 tentang hipertensi gestasional. Menampilkan hubungan dosis respons antara konsentrasi $\mathrm{Hb}$ ibu dan risiko hasil yang merugikan pada bayi dan ibu ${ }^{(17)}$.

Hasil penelitian menunjukkan bahwa ibu faktor usia kehamilan, jumlah paritas, umur ibu, tinggi badan, komplikasi persalinan, riwayat penyakit dan $\mathrm{K} 4$ berpengaruh pada persalinan sesar dengan hasil $(\mathrm{p}<0,24)$. Hal ini ditunjukkan dengan hasil $\mathrm{P} \leq 0,001$ dengan total $\mathrm{SC}$ sebesar $18,0 \%$ dibandingkan dengan ibu yang tidak memiliki komplikasi 8,5\% cenderung melahirkan dengan persalinan sesar. Menurut Gonzales GF dkk komplikasi pada kehamilan seperti anemia, masalah pada janin, manifestasi klinis preeklampia yaitu tekanan darah tinggi, oedema dan nyeri kepala lebih berisiko melahirkan secara sesar dibandingkan ibu yang tidak memiliki riwayat penyulit pada saat hamil. Hasil penelitian Peru menunjukkan bahwa ibu dengan preeklampsia kemungkinan besar menjalani persalinan sesar dibandingkan persalinan normal secara pervaginam ${ }^{(18)}$. 
Resiko anemia pada kehamilan mengalami peningkatan karena kebutuhan pembentukan sel darah merah dan perkembangan plasenta dan janin meningkat pada saat ibu hamil. Kekurangan zat besi merupakan hal umum yang sering teradi pada ibu hamil. Anemia pada ibu hamil menjadi penyebab bayi premature, persalinan sesar, transfuse RBC (Packed Red Blood Cell), BBLR, skor APGAR $<7$ dan efek jangka panjangnya adalah pada perkembangan mental dan psikomotor pada anak ${ }^{(19)}$.

Kejadian anemia pada trimester I $(\mathrm{p}<0,001)$ dan trimester II $(\mathrm{p}<0,005)$ lebih beresiko mengalami persalinan dengan SC ${ }^{(20)}$. Hal ini disebabkan oleh penurunan kadar serum ferritin pada ibu hamil yang meningkatkan resiko persalinan dengan sesar ${ }^{(21)}$.

\section{Dampak Anemia Defisiensi Besi pada Ibu Hamil dengan Perkembangan Mental Anak}

Kekurangan zat besi yang cukup, pada umumnya terjadi selama kehamilan dan pada masa perkembangan bayi, hal ini memiliki kemungkinan efek buruk melalui peran zat besi dalam fungsi otot dan otak. Banyak faktor yang dapat mempengaruhi perkembangan keterampilan motorik salah satunya adalah nutrisi. Para peneliti menyimpulkan bahwa suplementasi zat besi jangka panjang (> 2 bulan) selama masa bayi dapat meningkatkan perkembangan motorik. Juga terdapat sedikit penelitian mengenai hasil motorik pada masa bayi dengan suplementasi zat besi selama masa kehamilan. Hasil penelitian dengan Peabody Developmental Motor Scale menunjukkan $\mathrm{P}<001$; refleks, $\mathrm{P}=03$; stasioner, $\mathrm{P}<001$; dan penggerak, $\mathrm{P}<001$ yaitu suplementasi zat besi pada masa kehamilan tidak meningkatkan skor motorik pada bayi tetapi suplementasi zat besi pada masa bayi meningkatkan skor motorik sebesar 0.3 SD ${ }^{(22)}$.

Anemia mengakibatkan perubahan kerja di dalam otak sehingga dapat mengalami gangguan fungsi neurotransmitter dan mielinisasi sehingga anak kecil dengan anemia berisiko mengalami keterlambatan fungsi kognitif, sosial-emosional dan kemampuan beradaptasi hingga keterlambatan perkembangan bahasa dan motorik (16).

Anemia selama kehamilan dapat memiliki konsekuensi yang merusak bagi perkembangan janin melalui ketersediaan zat besi yang hilang untuk perkembangan saraf janin. Rawannya janin selama fase ini membuatnya rentan terhadap penyakit termasuk yang disebabkan oleh defisiensi mikronutrien ibu prenatal, yang dapat berdampak buruk pada otak janin dan fungsi kognitif bahkan setelah lahir. Sementara itu faktor yang terkait dengan fungsi kognitif bayi yang tertunda atau tidak optimal telah terbukti menjadi indikasi ketidaksiapan anak untuk sekolah ${ }^{(22)}$.

Anemia yang di diagnosis pada awal kehamilan dengan peningkatan risiko perkembangan gangguan spektrum autisme (ASD), gangguan attention-deficit / hyperactivity (ADHD), dan terutama disabilitas intelektual (ID) pada keturunannya. Anemia yang didiagnosis selama 30 minggu pertama kehamilan dikaitkan dengan peningkatan risiko tersebut. Hal ini ditunjukkan oleh hasil penelitian dengan diagnosis ASD (rasio odds [OR], 1,44; 95\% CI, 1,13-1,84), ADHD (OR, 1,37; 95\% CI, 1,14 1.64), dan ID (OR, 2.20; 95\% CI, 1.61-3.01) yang menunjukkan anemia pada usia kehamilan 30 minggu atau kurang dikaitkan dengan sedikitnya peningkatan risiko pada ASD dan ADHD pada keturunan tetapi memiliki peningkatan risiko ID yang lebih besar. Anemia pada kehamilan dapat menyebabkan kekurangan zat besi di otak janin yang sedang berkembang. Zat besi diperlukan untuk sejumlah proses perkembangan seperti myelination dan dendrite arborization dan untuk sintesis neurotransmitter monoamine, yang terlibat dalam penyebab ASD dan ADHD. Karena hemoglobin eritrosit merupakan hal penting untuk pengangkutan oksigen, ibu yang anemia suplai oksigen ke janin yang sedang berkembang mungkin terbatas sehingga menyebabkan peningkatan risiko hipoksia ${ }^{(23)}$.

\section{KESIMPULAN DAN SARAN}

\section{Kesimpulan}

Anemia pada kehamilan karena kekurangan zat besi dapat menyebabkan hasil pengeluaran (outcome) yang buruk terhadap ibu dan bayinya. Dampak yang dapat diakibatkan dari anemia pada kehamilan yaitu peningkatan resiko kelahiran premature dan BBLR, perdarahan postpartum dan kematian ibu, resiko persalinan section cesarea (SC) dan berpengaruh pada keterlambatan dan terhambatnya perkembangan mental anak. Selain itu dampak lain yang juga dapat terjadi pada ibu hamil anemia yaitu peningkatan resiko preeklamsia, solusio plasenta dan gagal jantung.

\section{Saran}



Vol. 16 No. 3 September - Desember 2021

Saran untuk literature review yang akan datang diharapkan dapat menggunakan sumber data yang lebih banyak dan artikel yang digunakan adalah artikel yang terbaru dan tidak kurang dari 5 tahun terakhir agar rujukan yang didapatkan dapat lebih maju seiring dengan perkembangan jaman.

\section{DAFTAR PUSTAKA}

1. Collaborators G 2016 D And II And P. Global, Regional, And National Incidence, Prevalence, And Years Lived With Disability For 328 Diseases And Injuries For 195 Countries, 1990-2016: A Systematic Analysis For The Global Burden Of Disease Study 2016. Lancet. 2017;390:1211-59.

2. Cappellini MD, Musallam KM, Taher AT. Iron Deficiency Anaemia Revisited. JIM [Internet]. 2019;287:153-170. Available From: Https://Onlinelibrary.Wiley.Com/Doi/Epdf/10 $.1111 /$ Joim. 13004

3. Achebe MM, Gafter-Gvili A. How I Treat Anemia In Pregnancy: Iron, Cobalamin, And Folate. Am Soc Hematol. 2017;129(8):940-9.

4. Smith C, Teng F, Joseph KS, Branch E. Maternal And Perinatal Morbidity And Mortality Associated With Anemia In Pregnancy. Med Complicat Pregnancy. 2019;134(6):1234-44.

5. Lin L, Wei Y, Zhu W, Wang C, Su R, Feng H, Et Al. Prevalence, Risk Factors And Associated Adverse Pregnancy Outcomes Of Anaemia In Chinese Pregnant Women: A Multicentre Retrospective Study. BMC Pregnancy Childbirth [Internet]. 2018;18:111. Available From: Https://Www.Ncbi.Nlm.Nih.Gov/Pmc/Article s/PMC5914057/

6. Larumpaa FS, Suparman E, Lengkong R. Hubungan Anemia Pada Ibu Hamil Dengan Kejadian Persalinan Prematur Menurut World Health Organization ( WHO ) Persalinan Prematur Adalah Persalinan Yang Terjadi Antara Usia Hari Pertama Haid Terakhir Pada Siklus 28 Hari . 1 Sampai Saat Ini Mortalitas Dan M. J Kesehat Masy. 2017;5:11-5.

7. Sá SA De, Willner E, Aguiar T, Pereira D, Souza VR De, Boaventura GT, Et Al. Original / Pediatría Anemia In Pregnancy: Impact On Weight And In The Development Of Anemia In Newborn. Nutr Hosp. 2015;32(5):2071-9.

8. Means RT. Iron Deficiency And Iron Deficiency Anemia : Implications And Impact In Pregnancy , Fetal Development, And Early Childhood Parameters. Nutrients.
2020;12:447.

9. Yunita Haryanti S, Rahayuning Pangestuti, Dina Kartini A. ANEMIA DAN KEK PADA IBU HAMIL SEBAGAI FAKTOR RISIKO KEJADIAN BAYI BERAT LAHIR RENDAH (BBLR). J Kesehat Masy. 2019;7:322-9.

10. Kumari S, Garg N, Kumar A, Kumar P, Guru I, Ansari S, Et Al. Maternal And Severe Anaemia In Delivering Women Is Associated With Risk Of Preterm And Low Birth Weight : A Cross Sectional Study From Jharkhand, India. One Heal [Internet]. 2019;8(February):100098. Available From: Https://Doi.Org/10.1016/J.Onehlt.2019.10009 8

11. Rahman A, Khan N, Rahman M. Public Health In Practice Maternal Anaemia And Risk Of Adverse Obstetric And Neonatal Outcomes In South Asian Countries: A Systematic Review And Meta-Analysis. Public Heal Pract. 2020;1(December 2019):1-9.

12. Sehgal R, Kriplani A, Vanamail P, Maiti L, Kandpal S, Kumar N. Assessment And Comparison Of Pregnancy Outcome Among Anaemic And Non Anaemic Primigravida Mothers. Indian J Public Heal | [Internet]. 2016;60(3):188-95. Available From: Https://Pubmed.Ncbi.Nlm.Nih.Gov/27561397 /

13. Pratama Husada Widoyoko A, Septianto R. PENGARUH ANEMIA TERHADAP KEMATIAN MATERNAL. J Penelit Perawat Prof. 2020;2:1-6.

14. Satriyandari Y, Hariyati NR. Faktor-Faktor Yang Mempengaruhi Kejadian Perdarahan Postpartum. J Heal Stud. 2017;1(2):49-64.

15. Daru J, Zamora J, Fernández-Félix BM, Vogel J, Oladapo OT, Morisaki N, Et Al. Articles Risk Of Maternal Mortality In Women With Severe Anaemia During Pregnancy And Post Partum : A Multilevel Analysis. Lancet Glob Heal. 2018;6(5):548-54.

16. M. Abu-Ouf N, M. Jan M. The Impact Of Maternal Iron Deficiency And Iron Deficiency Anemia On Child's Health. Saudi Med. 2015;36(2):146-9.

17. Jung J, Rahman M, Rahman S, Swe KT, Islam R, Rahman O, Et Al. Effects Of Hemoglobin Levels During Pregnancy On Adverse Maternal And Infant Outcomes : A Systematic Review And Meta-Analysis. Ann N Y Acad Sci. 2019;1450:69-82.

18. Sihombing NM, Saptarini I, Putri DSK. Determinan Persalinan Sectio Caesarea Di Indonesia (Analisis Lanjut Data Riskesdas 2013). J Kesehat Reproduksi. 2017;8(1):6373. 
19. Roy NBA, Pavord S. The Management Of Anaemia And Haematinic Deficiencies In Pregnancy And Post-Partum. Transfus Med. 2018;28(2):107-16.

20. Heydarpour F, Soltani M, Najafi F, Tabatabaee HR, Etemad K, Hajipour M, Et Al. Maternal Anemia In Various Trimesters And Related Pregnancy Outcomes: Results From A Large Cohort Study In Iran. Iran J Pediatr. 2019;29(1):1-7.

21. Mccarthy EK, Kenny LC, Hourihane JO, Irvine AD, Murray DM, Kiely ME. Impact Of Maternal, Antenatal And Birth-Associated Factors On Iron Stores At Birth: Data From A Prospective Maternal-Infant Birth Cohort. Eur J Clin Nutr [Internet]. 2017;71(6):782-7. Available From: Http://Dx.Doi.Org/10.1038/Ejcn.2016.255

22. Angulo-Barroso RM, Li M, Santos DCC, Bian Y, Sturza J, Jiang Y, Et Al. Iron Supplementation In Pregnancy Or Infancy And Motor Development: A Randomized Controlled Trial. Pediatrics [Internet]. 2016;137(4). Available From: Https://Pediatrics.Aappublications.Org/Conte nt/Pediatrics/137/4/E20153547.Full.Pdf

23. Wiegersma AM, Dalman C, Lee BK, Karlsson H, Gardner RM. Association Of Prenatal Maternal Anemia With Neurodevelopmental Disorders. JAMA Psychiatry [Internet]. 2019;76(12):1294-304. Available From: Https://Jamanetwork.Com/Journals/Jamapsyc hiatry/Fullarticle/2751260 